Nippon Suisan Gakkaishi $\quad$ 70(1), 22-30 (2004)

\title{
サンゴ礁域に放流したスジアラ人工種苗の滞留, 摂䭒打よび被食に及ぼす囲い網による環境馴致効果
}

\author{
浜崎活幸, * 竹内宏行, ${ }^{\mathrm{a}}$ 塩澤 聡, ${ }^{\mathrm{b}}$ 照屋和 久 $\mathrm{c}$
}

(2003 年 1 月 20 日受付, 2003 年 8 月 6 日受理)

独水産総合研究センター八重山栽培漁業センター

Effects of acclimation to the natural environment before release on retention rate, feeding condition and predation of hatchery-reared juveniles

of the coral trout Plectropomus leopardus released on a coral reef

\section{KATSUYUKI HAMASAKI, ${ }^{*}$ HIROYUKI TAKEUCHI, ${ }^{a}$ SATOSHI SHIOZAWA ${ }^{b}$ AND KAZUHISA TERUYA ${ }^{c}$}

Yaeyama Station, National Center for Stock Enhancement (NCSE), Ishigaki, Okinawa 907-0451, Japan

\begin{abstract}
Retention rate, feeding condition and predation of hatchery-reared juveniles of the coral trout Plectropomus leopardus released on a coral reef in Urasoko Bay, Ishigaki Island were investigated to evaluate the effectiveness of acclimation of juveniles to the natural environment before release. Two experiments were conducted and 2000 juveniles [mean total length (TL), $137 \mathrm{~mm}$ ] and 900 juveniles (mean TL, $79 \mathrm{~mm}$ ) were stocked in a net cage $\left(400 \mathrm{~m}^{2}\right)$ which was set on the release site in the first and second trials, respectively. After acclimation for 7 days in the net cage, acclimated juveniles (test group) were released with the control groups of 2000 juveniles (mean TL, $142 \mathrm{~mm}$ ) in the first trial and 900 juveniles (mean TL, $86 \mathrm{~mm}$ ) in the second trial. Test and control groups were distinguished by different color tags. The second release experiment could not be conducted satisfactorily due to a typhoon. Judging from the feeding incidence, changes of condition factor and visceral weight index of juveniles after release in the first trial, it was considered that juveniles of the test group were more acclimated to the natural environment than those of the control group. Furthermore, juveniles of the test group tended to be less vulnerable to predation by piscivorous animals than those of the control group due to the improvement of behavior of lurking in the coral rubble.
\end{abstract}

キーワード : スジアラ, 人工種苗, 馴致, 放流, 滞留, 摄餌, 被食

スジアラPlectropomus leopardus は南日本からインド 洋に分布する大型のハ夕類で, ${ }^{1)}$ 沖縄県では重要な沿岸 漁業資源である。吕) 日本栽培漁業協会八重山事業場 (現，水産総合研究センター八重山栽培漁業センター) はスジアラの栽培漁業技術開発研究の一環として, 1991 年から 1999 年までに合計 8 万尾余りの人工種苗 （平均全長 75〜321 mm）を沖縄県の石西礁湖で放流し ているが，再捕率は $0.014 \%$ で極めて低い值を示してい る。年この原因を把握するために，著者らは放流したス ジアラ人工種苗の滞留, 摂飭抢よび被食状況を調査し,
放流初期の減耗要因として被食の重要性を指摘した。5-7) また，放流したスジアラ人工種苗の拱餌率は低く, ${ }^{5-8)}$ これは放流時のハンドリング，あるいは未知の環境にお かれたことによるストレス状態に起因するものと考えら れた。7,9)

放流効果を上げるには放流種苗が資源に加入する割 合，すなわち添加効率 10 の向上が不可欠であり，その ためには放流初期の減耗を防ぐ必要がある。そこで本研 究では, 放流初期のスジアラ人工種苗の拱䬣率を向上さ せ，被食を回避する放流手法を開発する一環として，放

* Tel : 81-980-88-2136. Fax : 81-980-88-2138. Email : hamak@fra.affrc.go.jp

a 現所属: 独水産総合研究センター宮津栽培漁業センター (Miyazu Station, NCSE, Miyazu, Kyoto 626-0052, Japan)

b 現所属: 独水産総合研究センター小浜栽培漁業センター (Obama Station, NCSE, Obama, Fukui 917-0177, Japan)

c 現所属：独水産総合研究センター上浦栽培漁業センター (Kamiura Station, NCSE, Kamiura, Oita 879-2602, Japan) 
流場に設置した囲い網に種苗を収容し，その環境に短期 間馴致して放流した種苗群と直接放流した種苗群につい て，放流初期の滞留，拱䬳抢よび被食状況を調査し，摂 餌率の向上と被食回避に及ぼす環境馴致の効果を評価す ることを試みた。

\section{材料および方法}

スジアラ種苗 放流実験は 1998 年 4 5 月および 10 月に計 2 回行った。第 1 回放流群として，1997 年に八 重山事業場において生産し, 中間育成した 1 歳の種苗 4000 尾を用いた。また, 第 2 回放流群として, 1998 年 に生産した当歳の種苗 1800 尾を用いた。

両実験とも放流場に設置した囲い網内で環境に馴致し て放流する群（馴致放流群） と直接放流する群（直接放 流群）を設けた。第 1 回放流では囲い網へ収容する 21 日前に赤色と白色のアンカータグ（長さ $50 \mathrm{~mm}$; 科研 共栄会，広島）をそれぞれ 2000 尾の第 1 背鰙基部に装 着した。また, 第 2 回放流では, 囲い網への収容 11 日 前に桃色と緑色のリボンタグ（長さ $30 \mathrm{~mm}$; 科研共栄 会，広島）をそれぞれ 900 尾の第 1 背䰹基部に装着し た。標識を装着した種苗は実験開始まで陸上水槽で配合 飼料を給䭒して育成した。第 1 回放流における馴致放 流群の囲い網収容時の平均全長は $137 \mathrm{~mm} （ 107 \sim 161$ $\mathrm{mm}, n=50$ ) で, 直接放流群の放流時の平均全長は

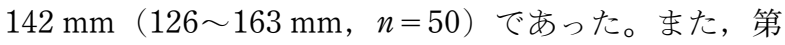
2 回放流における馴致放流群の囲い網収容時の平均全長 は $78.6 \mathrm{~mm} （ 69.7 \sim 86.5 \mathrm{~mm}, n=30 ）$ で, 直接放流群 の放流時の平均全長は $85.9 \mathrm{~mm} \quad(78.0 \sim 98.2 \mathrm{~mm}, n=$ 32)であった。

放流場 石垣島浦底湾のサンゴ礁域を放流場とした (Fig. 1)。放流地点にはロープで $50 \times 50 \mathrm{~m}$ の調査枠を 設けるとともに， $50 \mathrm{~m}$ 調查枠を囲うように $100 \mathrm{~m}$ の正 方形枠も設けた。 $50 \mathrm{~m}$ 枠内には南北に $10 \mathrm{~m}$ 間隔, 東 西に $5 \mathrm{~m}$ 間隔でラインを設置し， $5 \times 10 \mathrm{~m}$ のコドラー 卜50 個を設定した。50 m 枠内の底質はサンゴ瓦碩，岩 盤, 造礁サンゴによって構成されており，水深は $0.9 \sim$ $2.5 \mathrm{~m}$ であった（Fig. 1)。第 2 回放流では，放流海域の サンゴの $90 \%$ 以上が夏季の高水温による白化現象で死 滅していた。

調査期間中の水温は第 1 回放流が $24.7 \sim 26.6^{\circ} \mathrm{C}$, 第 2 回放流が $27.7 \sim 29.1^{\circ} \mathrm{C}$ の範囲で推移した。

囲い網による環境馴致 $50 \mathrm{~m}$ 調查枠のサンゴ山を囲 うように $20 \times 20 \mathrm{~m}$ のフロート付き側張りロープを海面 に設置し，その側張りに高さ $3 \mathrm{~m}$ ，一辺の長さ $20 \mathrm{~m}$ の 囲い網(90 経モジ網製で底網なし)を敷設した(Fig. 1)。 囲い網の下辺には鉄製のチェーンを装着し，下辺を海底 に沈設した。

第 1 回放流では 4 月 8 日に 2000 尾を, 第 2 回放流で

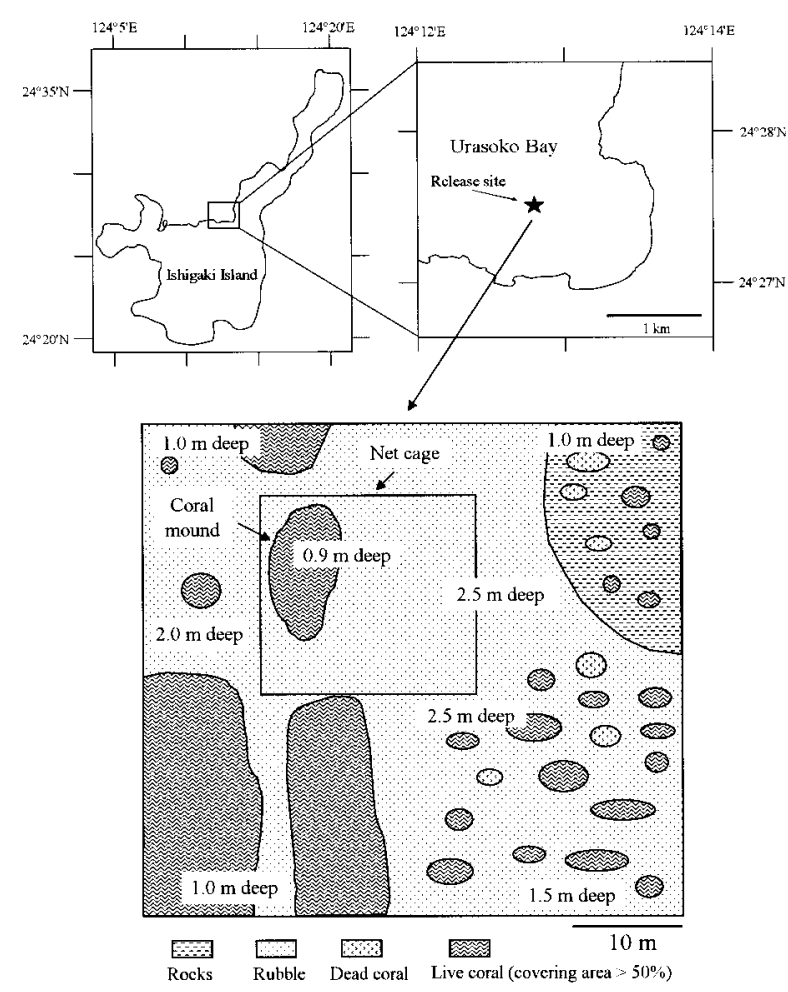

Fig. 1 Release site of the hatchery-reared coral trout juveniles. A square section $(50 \times 50 \mathrm{~m})$ which was surrounded by a $100 \times 100 \mathrm{~m}$ square section was marked on the release site. A net cage $\left(400 \mathrm{~m}^{2}\right)$ without a bottom was set within the $50 \times 50 \mathrm{~m}$ square section.

は 10 月 5 日に 900 尾を囲い網に収容し，環境馴致を開 始した。囲い網による環境馴致期間は 7 日間とし，そ の間に種苗への給餌は行わなかった。馴致期間中にはほ ぼ毎日囲い網内の種苗の状況を潜水観察した。第 1 回 放流では放流前日に若干の種苗の逃亡が認められたこと から (未計数), 第 2 回放流では囲い網内の種苗を目視 計数するとともに，囲い網外の調査枠に抢ける観察も実 施した。

放流方法第 1 回放流は 4 月 15 日に， 2 回目は 10 月 12 日に実施した。第 1 回放流では, 陸上水槽で育成 していた直接放流群 2000 尾を，また第 2 回放流では同 様に 900 尾を放流当日にいったん囲い網内に收容し， 収容後直ちに囲い網を引き揚げることによって馴致放流 群と直接放流群を同時に放流した。

滞留調查 種苗の滞留状況調查は, 第 1 回放流では 放流当日から 40 日後までの期間に 9 回，第 2 回放流で は 7 日後までの期間に 5 回実施し, 調査員 $3 \sim 4$ 名で 50 $\mathrm{m}$ 調查枠内と $50 \mathrm{~m}$ 枠と $100 \mathrm{~m}$ 枠間のエリアで素潜りに よる種苗の計数を実施した。スジアラ種苗はテーブルサ ンゴ等の隙間に隠れている場合が多く，テーブルサンゴ 
等の近辺において種苗を 1 尾でも発見した場合, 潜水 して隙間に隠れている種苗を可能な限り計数した。潜水 観察は放流当日には放流 2 時間後, それ以外の調査日 には 9 時から 11 時の間に行った。

摂餌調査 種苗の摂飭状況を把握するために, 第 1 回放流の馴致放流群については, 囲い網への収容日と囲 い網を解放するまでに 1 回, また放流当日から 23 日後 までの期間に 5 回, 直接放流群については放流当日か ら 23 日後までの期間に 6 回，放流種苗を銛突きで再捕 した。第 2 回放流では, 馴致放流群については囲い網 への收容日と囲い網を解放するまでに 1 回, 放流後は 両群とも放流当日と 8 日後に 2 回, 放流種苗の再捕を 試みた。本種は昼行性で, 夜間はサンゴ等の隙間で睡眠 状態にあり，再捕が容易になることから，種苗の再捕は 夜間 20 時以降に実施した。再捕した種苗は氷蔵し, 実 験室に持ち帰り, 体重を $0.1 \mathrm{~g}$ 単位で, 全長と体長を $0.1 \mathrm{~mm}$ 単位で測定し, 内臓を摘出して胃の内容物を除 いた内臓重量を $0.01 \mathrm{~g}$ 単位で秤量した。また, 肝臓に ついても同様に秤量した。胃の内容物と腸は $10 \%$ ホル マリンで固定・保存し，後日内容物を検鏡した。胃ある いは腸に内容物（腸の場合は黒色系の糞塊）が確認され た場合，その個体は拱慨していたものとした。また，消 化が進行した内容物のうち, 耳石, 骨片あるいは鱗が確 認されたものは魚類を，またクチクラの場合には甲殼類 を摂䭅していたものと判断した。

種苗の栄養状態の指標として, スジアラ人工種苗 $\left.{ }^{9}\right) や$ マダイ Pagrus major 人工種苗11)において, 飢餓の進行 にともない減少することが報告されている肥満度（胃内 容物重量を除いた体重 $/$ 体長 $\left.{ }^{3} \times 10^{6}\right)$, 内臓重量指数 （胃内容物重量を除いた内臓重量/体長 ${ }^{3} \times 10^{7}$ ）抢よび 肝臓重量指数 (肝臓重量 $/$ 体長 $3 \times 10^{7}$ ) を算出した。

被食調査 放流種苗の被食状況を調査するために, 第 1 回放流では毎回の滞留状況調査終了時に銛で, また放 流 3 日後, 8 日後および 13 日後の 20 時から 23 時の間 に銛で，睡眠状態にある肉食性魚類等を採集した。ま た, 同日に 1 枚刺し網（目合い $38 \mathrm{~mm}$, 高さ $1.5 \mathrm{~m}$, 長さ合計 $200 \mathrm{~m}$ ) を 18 時頃に設置して 22 時頃に回収 した。刺し網は 3 日後の調査が $50 \mathrm{~m}$ 枠の東側, 8 日後 が南側および 13 日後が北側に設置した。第 2 回放流で は毎回の滞留状況調査終了時と放流 2 日後の 20 時から 22 時の間に銛で肉食性魚類等を採集した。銛による採 集は調査枠を中心に周囲 100 150 m までの範囲で実施 した。採集個体は氷蔵し，実験室へ搬入して種を同定す るとともに体サイズを測定した。その後, 消化管を摘出 して胃内容物を調査した。胃内容物として出現した生物 は放流種苗, それ以外の魚類, 甲殻類抢よびその他とし て整理し, 放流種苗については馴致放流群と直接放流群 を区別して記録した。また，タグのみが出現した場合も
スジアラ放流種苗が捕食されていたものとした。

統計処理 2 群の肥満度, 内蔵打よび肝蔵重量指数の 差をMann-Whitney の $U$ 検定で比較し，有意水準を 5 \%に設定した。

\section{結果}

\section{滞留状況}

1. 第 1 回放流 囲い網解放後の調查枠内における馴 致放流群と直接放流群の個体数変動を, 放流尾数に対す る観察尾数の百分率（便宜上, 滞留率と呼称する）とし て Fig. 2 に示した。馴致放流群の $50 \mathrm{~m}$ 枠内における滞 留率は放流 2 時間後の調查時にはすでに激減し，5.3\% にすぎなかった。 $50 \mathrm{~m}$ 枠内の滞留率はその後徐々に減 少し, 放流 19 日後以降には $1 \%$ 以下となり, 調査最終 日の 40 日後には $0.1 \%$ であった。一方， $50 \sim 100 \mathrm{~m}$ 枠

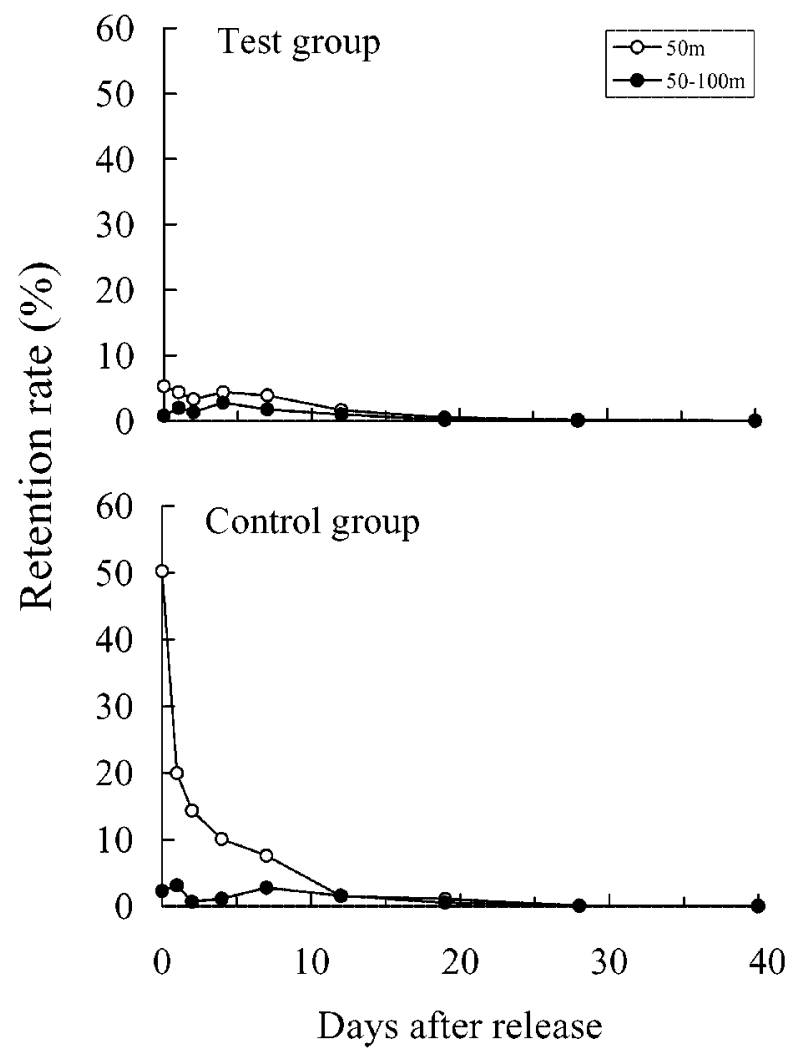

Fig. 2 Retention rate of the hatchery-reared coral trout juveniles released on the coral reef in the first release trial. Juveniles of the test group were released after being acclimated to the natural environment for 7 days by stocking in a net cage which was set on the release site. Juveniles of the control group were released without acclimation. Retention rate was expressed as the percentage of the number of juveniles counted by divers to the number of juveniles released. The released juveniles were counted in the $50 \times 50 \mathrm{~m} \mathrm{sec}$ tion $(O)$ and in the area between the $50 \times 50 \mathrm{~m}$ and $100 \times 100 \mathrm{~m}$ sections $(\bullet)$. 
間の滞留率は当初の $0.8 \%$ から 4 日後には $2.8 \%$ まで上 昇し，19 日後に $0.2 \%$ を記録して以後確認できなかっ た。

直接放流群の $50 \mathrm{~m}$ 枠内に抢ける滞留率は放流 2 時間 後には $50.3 \%$ を示し，多くの個体がサンゴ山（Fig. 1) に分布していた。 $50 \mathrm{~m}$ 枠内の滞留率はその後指数関数 的に減少し，12 日後以降には馴致放流群と大差ない值 を示した。50～100 m 枠間の滞留率は放流当日と翌日 にはそれぞれ $2.3 \%$ と $3.2 \%$ を示し，その後 $0.6 〜 2.8 \%$ の範囲で推移して 28 日後以降 $0.1 \%$ まで低下した。

放流 12 日後, 19 日後および 28 日後の調查時に標識 の脱落により群判別ができない個体がみられ，観察した 種苗数に占める割合はそれぞれ $4.1 \%, 23.3 \%$ および $20.0 \%$ であった。

2. 第 2 回放流滞留率の推移をFig. 3 に示した。 第 2 回放流では, 囲い網内で環境へ馴致中の種苗を計 数したところ，囲い網への收容尾数に対する収容翌日の 種苗計数値の割合は $76.2 \%$ であった（便宜上，この割 合を見かけの滞留率と呼称する)。見かけの滞留率は収 容 3 日後の $18.6 \%$ まで急減し，その後緩やかに減少し て囲い網解放直後には $7.3 \%$ を示した。なお，囲い網で 馴致を開始して 2 日後, 3 日後, 4 日後打よび 6 日後に それぞれ 17 尾（囲い網への収容尾数に対する割合は $1.9 \%) ， 20$ 尾 (2.2\%)，26尾（2.9\%）および 13 尾 (1.4\%) の種苗が囲い網の周囲で認められた。

馴致放流群の囲い網解放後の $50 \mathrm{~m}$ 枠内における滞留 率は，当初の $7.3 \%$ 加徐々に減少する傾向を示し，放 流 3 日後には 5.1\% を示した。一方，50〜 $100 \mathrm{~m}$ 枠間の 滞留率は $0.2 \sim 0.3 \%$ で推移した。直接放流群の $50 \mathrm{~m}$ 枠 内に打放流当日の滞留率は $38.8 \%$ を示し, 翌日に は $10.3 \%$ まで減少して 3 日後まで $10 \%$ 前後で推移し た。直接放流群の $50 \sim 100 \mathrm{~m}$ 枠間の滞留率は囲い網収 容群よりも高い值を示し， 3 日後をで $1.5 \%$ 前後の值で 推移した。調査期間中に標識の脱落により群判別ができ ない個体がみられ，放流当日から 3 日後までに観察し た種苗数に占める割合は，それぞれ 4.6\%, 14.9\%, 29.1 \% および $30.8 \%$ であった。

放流 3 日後以降も調査を継続する計画であったが, 台風によって調查枠が破損したため，放流 7 日後に調 査を終了した。終了時の観察尾数は, 馴致放流群が 2 尾，直接放流群が 5 尾であった。なお，第 1 回および 第 2 回放流調查とも, 放流した人工種苗と同サイズの スジアラ天然魚の分布は確認されなかった。

\section{摂餌状況}

1. 第 1 回放流 馴致放流群では囲い網内での育成時 （放流 4 日前）に $6.7 \%$ の個体がデバスズメダイChromis viridis を摂䭒していた（Table 1)。また，囲い網内 で実際にデバスズメダイを捕食する種苗も観察した。放

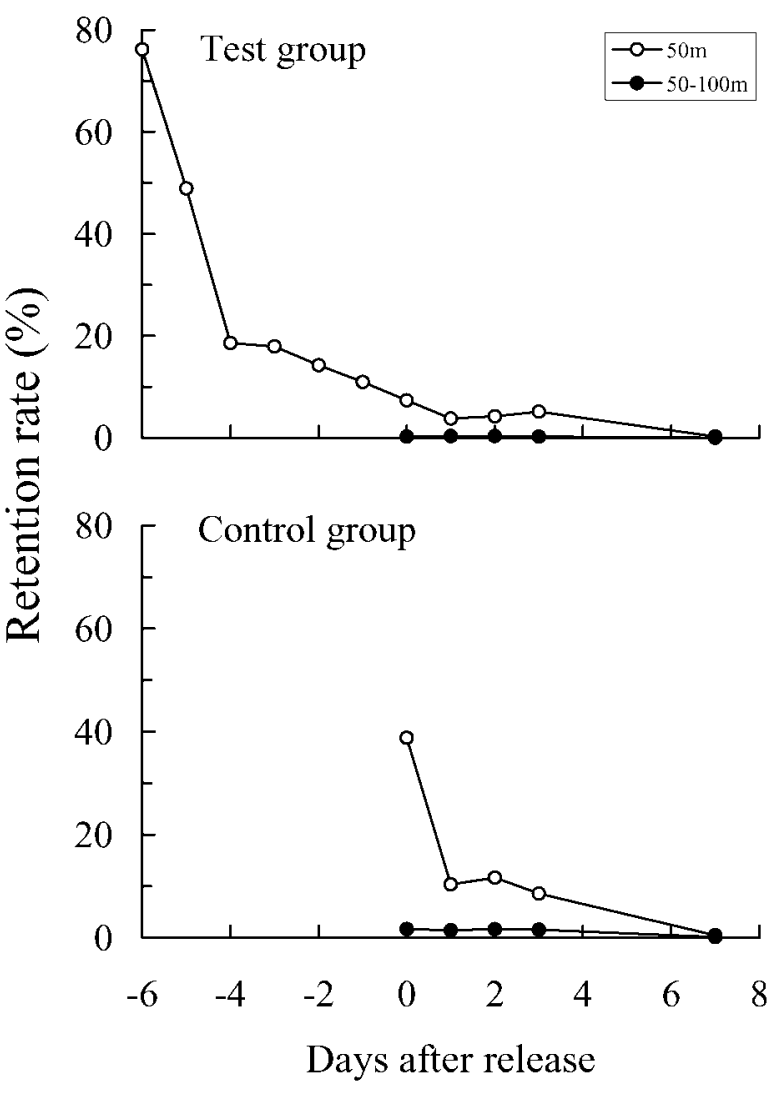

Fig. 3 Retention rate of the hatchery-reared coral trout juveniles released on the coral reef in the second release trial. See Fig. 2 for details of the test and control groups and retention rate. In this trial, the number of juveniles in the test group was counted by divers in the net cage before release and the percentage of the number of counted juveniles before release to the number of stocked juveniles is tentatively shown as the retention rate. $\bigcirc, 50 \times 50 \mathrm{~m}$ section; $\bullet$, area between the $50 \times 50 \mathrm{~m}$ and $100 \times 100 \mathrm{~m}$ sections.

流 3 日後までの調査では, 拱餌個体は観察されなかっ たが，馴致放流群の拱餌個体率は 8 日後に $36.4 \%$ を示 し，13 日後には $71.4 \%$ に達した。直接放流群の摂餌個 体率は 8 日後に $7.1 \%$ を示し，その後増加して 13 日後 に 40.0\%，23 日後に 83.3\%に達した。両群のスジアラ 放流種苗が摄慨していた餌は主に魚類と甲殼類であり， 各䭒を拱慨していた種苗数の拱餌種苗数に対する割合は それぞれ 50.0\% と 53.8\%であった。消化管内容物重量 指数（消化管内容物重量/種苗体重）については，多く の種苗で内容物の消化が進んでいたため算出できなかっ た。

再捕種苗の肥満度, 内臓重量指数抒よび肝臓重量指数 の推移を Fig. 4 に示した。肥満度は両群とも直線的に 減少する傾向を示し, 両群に差は認められなかった（ $P$ $>0.05)$ 。馴致放流群の内臓重量指数は囲い網収容 3 日 後までと放流 8 日後までの減少率が大きく, 以後 7 前 

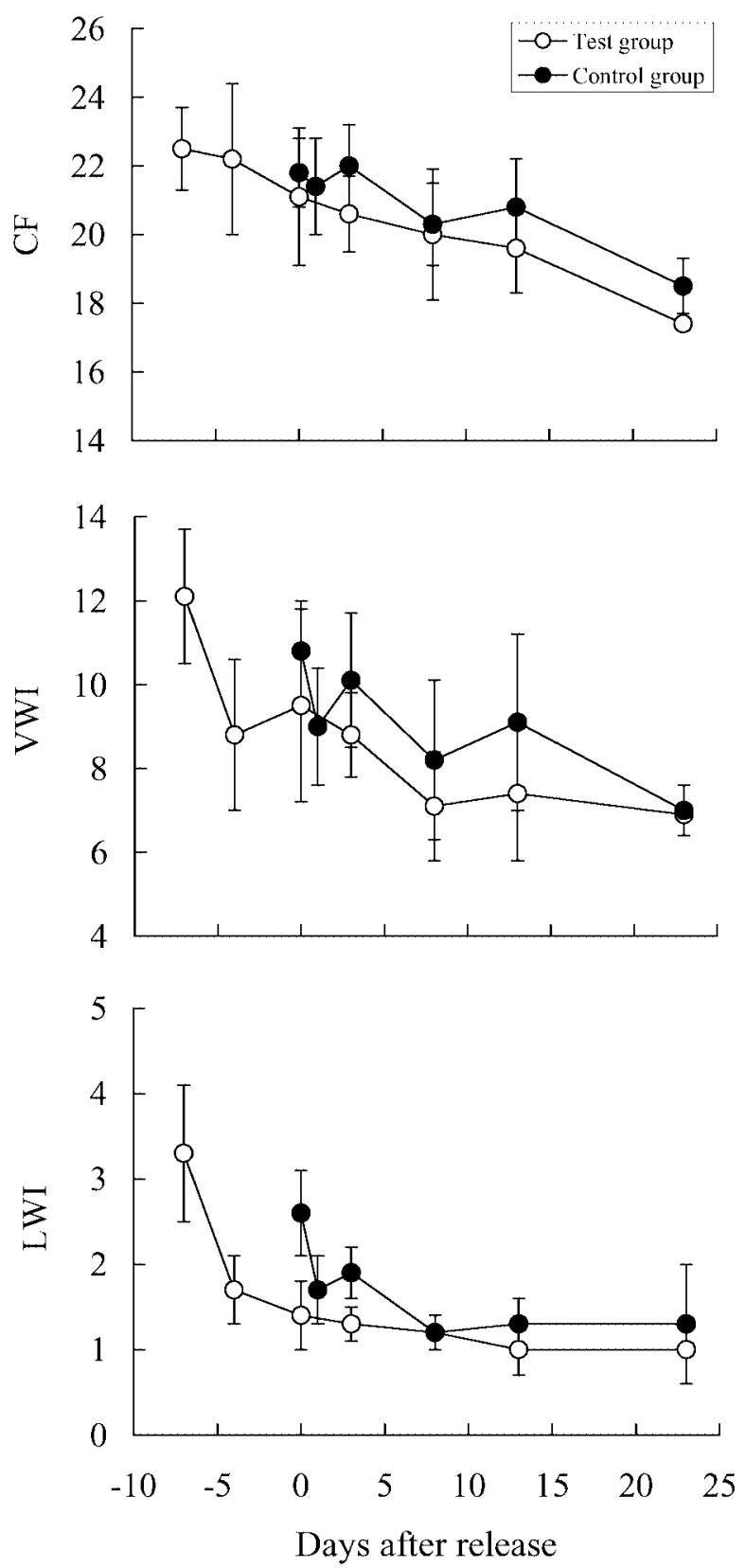

Fig. 4 Condition factor (CF), visceral weight (VWI) and liver weight indices (LWI) of the hatchery-reared coral trout juveniles after release in the first release trial. See Fig. 2 for details of the test and control groups. Condition factor $=($ body weight in $g) /($ standard length in $\mathrm{mm})^{3} \times 10^{6}$. Visceral and liver weight indices $=($ weight in $\mathrm{g}) /(\text { standard length in } \mathrm{mm})^{3} \times$ $10^{7}$. Vertical bars indicate the standard deviation.

後の值で安定した。直接放流群の内臟重量指数は馴致放 流群よりも高い傾向を示し, 放流 13 日後に有意差が認 められたが $(P<0.05)$ ，それ以降も低下傾向にあった。 馴致放流群の肝臓重量指数は囲い網収容 3 日後までの 減少率が大きく, その後 $1 \sim 1.4$ の範囲で推移した。直 接放流群の肝臓重量指数は馴致放流群よりも放流当日
$(P<0.001), 3$ 日後 $(P<0.01)$ および 13 日後 $(P<$ 0.05）に有意に高い值を示したが，23 日後には有意差 は認められなかった $(P>0.05)$ 。

2. 第 2 回放流 台風の影響によって種苗の再捕を計 画通りに行うことができず，馴致放流群については囲い 網収容日に 10 尾, 収容 6 日後に 10 尾を, 直接放流群 については放流日に 10 尾と放流 8 日後に 1 尾を再捕し たにすぎず，再捕種苗はいずれも摃䬣していなかった。 馴致放流群の囲い網収容日の肥満度, 内臟重量指数抒よ び肝臓重量指数の平均値土標準偏差はそれぞれ $25.1 \pm$ $2.2,25.9 \pm 3.6$ 抢よび $3.6 \pm 1.0$ であり, 収容 6 日後の值 はそれぞれ $22.4 \pm 1.1,15.5 \pm 2.2$ および $2.2 \pm 0.9$ であっ た。同様に，直接放流群の放流日の各測定值はそれぞれ $25.1 \pm 0.8,19.7 \pm 2.1$ 打よび $3.1 \pm 0.4$ であり，放流 8 日 後の值はそれぞれ $24.8,6.9$ および 0.7 であった。

\section{被食状況}

1. 第 1 回放流 放流後に銛によって採集した肉食性 生物は, 魚類 25 種 52 個体, 頭足類 3 種 12 個体および 爬虫類のウミへビ類 1 種 1 個体であり, 全個体の胃内 容物を調べた。をた，刺し網による採集生物は魚類 11 種 30 個体であり，そのうちプランクトン食魚と雑食魚 を除く 8 種 14 個体の胃内容物を調べた。胃内容物を調 べた個体のうち，17 種が魚類を捕食しており，17 種 54 個体のうち 8 種 9 個体が馴致放流群を，また 7 種 9 個 体が直接放流群を捕食していた（Table 2)。捕食生物の うち高頻度で放流種苗を捕食していたのはウツボ類，大 型のハタ類抢よびウミへビ類であり，二セゴイシウッボ Gymnothorax isingteena の 2 個体が合計 18 尾の放流種 苗を, ウミへビ類 Hydrophis sp.の 1 個体が 8 尾の放流 種苗を捕食していた。被食魚類の総数は 59 尾で，その うち 45 尾（76.3\%）が放流種苗であり，放流種苗の被 食尾数が多かった。また，被食種苗のうち 17 尾が馴致 放流群, 28 尾が直接放流群であり, 馴致放流群の被食 頻度が低い傾向を示した。

今回の調查においてスジアラ放流種苗を 1 尾でも捕 食していた生物種の放流種苗に対する捕食率（捕食個体 数/採集個体数）打よび放流種苗とその他魚類に対する 平均捕食尾数を，捕食生物の採集個体数が多かった放流 3 日後, 8 日後抢よび 13 日後で比較すると（Table 3), 捕食率は 8 日後まで高い值を示した。また, 平均捕食 尾数は 8 日後までは放流種苗に対する值が高かったが， 13 日後にはその他の魚類に対する值が増加していた。

2. 第 2 回放流 放流後に採集した生物は, 魚類 19 種 42 個体, 頭足類 2 種 2 個体抢よび爬虫類のウミへビ 類 1 種 1 個体であった。胃内容物調査は第 1 回放流調 查の結果に基づき，魚食性の 14 種 32 個体について実 施した（Table 2)。調査個体のうち，ドクウツボ Gymnothorax melanospilos，アオヤガラ Fistularia commer- 
Table 1 Feeding condition of hatchery-reared juveniles of the coral trout released on the coral reef in the first release trial

\begin{tabular}{|c|c|c|c|c|c|c|c|c|}
\hline \multirow{2}{*}{$\begin{array}{l}\text { Juvenile } \\
\text { group }\end{array}$} & \multirow{2}{*}{$\begin{array}{l}\text { Days } \\
\text { after } \\
\text { release }\end{array}$} & \multirow{2}{*}{$\begin{array}{l}\text { No. of } \\
\text { juveniles } \\
\text { collected }\end{array}$} & \multirow{2}{*}{$\begin{array}{l}\text { Total } \\
\text { length*2 } \\
\text { (mm) }\end{array}$} & \multicolumn{2}{|c|}{ Juveniles with food items } & \multicolumn{3}{|c|}{ Food items ${ }^{* 4}$} \\
\hline & & & & $n$ & $(\%) * 3$ & Fish & Decapods & Unidentified \\
\hline \multirow[t]{7}{*}{ Test } & -7 & 15 & $136 \pm 12$ & 0 & 0 & 0 & 0 & 0 \\
\hline & -4 & 15 & $140 \pm 9$ & 1 & 6.7 & 1 & 0 & 0 \\
\hline & 0 & 7 & $147 \pm 14$ & 0 & 0 & 0 & 0 & 0 \\
\hline & 3 & 10 & $157 \pm 7$ & 0 & 0 & 0 & 0 & 0 \\
\hline & 8 & 11 & $138 \pm 13$ & 4 & 36.4 & 2 & 0 & 2 \\
\hline & 13 & 14 & $150 \pm 14$ & 10 & 71.4 & 5 & 6 & 2 \\
\hline & 23 & 1 & 151 & 1 & 100 & 1 & 1 & 0 \\
\hline Total & & 73 & & 16 & & 9 & 7 & 4 \\
\hline \multirow[t]{6}{*}{ Control } & 0 & 15 & $140 \pm 7$ & 0 & 0 & 0 & 0 & 0 \\
\hline & 1 & 9 & $146 \pm 10$ & 0 & 0 & 0 & 0 & 0 \\
\hline & 3 & 6 & $154 \pm 11$ & 0 & 0 & 0 & 0 & 0 \\
\hline & 8 & 14 & $156 \pm 12$ & 1 & 7.1 & 0 & 1 & 0 \\
\hline & 13 & 10 & $153 \pm 11$ & 4 & 40.0 & 1 & 3 & 1 \\
\hline & 23 & 6 & $157 \pm 10$ & 5 & 83.3 & 3 & 3 & 0 \\
\hline Total & & 60 & & 10 & & 4 & 7 & 1 \\
\hline
\end{tabular}

Both stomach and intestines were examined.

*1 Juveniles of the test group were released after being acclimated to the natural environment for 7 days by stocking in a net cage without a bottom which was set on the release site. Juveniles of the control group were released without acclimation.

*2 Mean \pm standard deviation.

*3 Ratio to the number of juveniles collected.

*4 Each value indicates the number of coral trout juveniles which had preyed on each food item.

sonii, スジアラ天然魚打よびニジハタ Cephalopholis urodeta が放流種苗を捕食していた。被食魚類の総数は 24 尾で，そのうち 14 尾 (58.3\%) が放流種苗であった。 馴致放流群々直接放流群の被食尾数はそれぞれ 6 尾と 8 尾であり，馴致放流群の被食頻度が若干低い傾向を示し た。

第 1 回放流と同様に算出したスジアラ放流種苗を捕 食していた生物種の放流種苗に対する捕食率と平均捕食 尾数は，放流翌日が最も高い值を示した（Table 3）。

\section{考察}

滞留 直接放流群の放流当日の滞留率は 40 ～50\%の 値を示し, 以後指数関数的に減少した (Figs. 2, 3)。こ の滞留率の推移は, 照屋ら ${ }^{7)}$ が今回の放流海域の近辺に おいて同様の方法で調査した放流事例の結果とよく一致 した。一方, 第 2 回放流では, 囲い網内で環境へ馴致 中の種苗を計数したところ, 見かけの滞留率は当初の $76 \%$ から収容 3 日後の $19 \%$ 程度まで急減し, その後徐 々に低下して囲い網解放時には $7 \%$ 程度の值を示した (Fig. 3)。本調査では，テーブルサンゴ等の近辺におい て種苗を 1 尾でも発見した場合，潜水して隙間に隠れ ている種苗を可能な限り計数したが，それでも囲い網内 における放流までの見かけの滞留率は急減した。第 2 回放流では, 囲い網外への種苗の逃亡が認められたが,
囲い網への収容尾数に対する逃亡種苗の計数值の割合は $2 \%$ 程度で，見かけの滞留率の急減に影響を与えるほど の值とは考えにくいことから，この見かけの滞留率の急 激な低下は, 種苗がサンゴ等の奥深い間隙に隠れる能力 を向上させ，潜水観察者の種苗発見率が低下したことに 起因するものと考えられる。第 1 回放流に打ける放流 当日の低い滞留率（5％）もこのことによって説明可能 と考えられる。

放流種苗群を区別するために，今回は体外型タグ（ア ンカータグとリボンタグ）を採用したが，タグの脱落が 認められたことから，今後はイラストマー12)や凍傷標 識13)等も併用し, 放流群の識別を確実にする必要があ る。また，今回の被食状況調査においては，捕食されて いたスジアラ種苗の群を識別することができたが (Table 2), 消化が進んでいた被食魚の中には放流種苗 （特に標識が脱落した種苗）が含まれている可能性もあ ることから，今後の調査ではALCによる耳石標識14)で 放流群を識別することも必要である。

摂餌 スジアラ人工種苗は実験的にはデバスズメダイ を捕食することが可能と報告されているが, 9,15) 実際の 放流現場ではこれまで確認されていなかった。今回の第 1 回放流に抢いて, 囲い網に收容したスジアラ種苗が実 際にデバスズメダイを捕食することが確認された。飼育 条件下のスジアラ人工種苗のデバスズメダイに対する捕 
Table 2 Analysis of stomachs of piscivorous species collected during the first and second release trials

\begin{tabular}{|c|c|c|c|c|c|c|c|c|c|c|c|c|}
\hline \multirow{2}{*}{$\begin{array}{l}\text { Release } \\
\text { trial no. }\end{array}$} & \multirow{2}{*}{ Family } & \multirow{2}{*}{ Species (Japanese name) } & \multirow{2}{*}{$n$} & \multirow{2}{*}{$\begin{array}{l}\mathrm{BS}^{* 1} \\
(\mathrm{~mm})\end{array}$} & \multicolumn{5}{|c|}{$\begin{array}{l}\text { No. of individuals which had } \\
\text { preyed on each food item }\end{array}$} & \multicolumn{3}{|c|}{$\begin{array}{l}\text { Total no. of each food } \\
\text { item in stomachs }\end{array}$} \\
\hline & & & & & $\begin{array}{l}\text { Test } \\
\text { group*2 }^{* 2}\end{array}$ & $\begin{array}{l}\text { Control } \\
\text { group*2 }\end{array}$ & $\begin{array}{l}\text { Other } \\
\text { fish }\end{array}$ & Decapods & Others & $\begin{array}{l}\text { Test } \\
\text { group }\end{array}$ & $\begin{array}{l}\text { Control } \\
\text { group*2 }\end{array}$ & $\begin{array}{l}\text { Other } \\
\text { fish }\end{array}$ \\
\hline \multirow[t]{17}{*}{1} & Muraenidae & $\begin{array}{l}\text { Gymnothorax melanospilos } \\
\text { (Dokuutsubo) }\end{array}$ & 1 & 526 & 1 & 0 & 0 & 0 & 0 & 1 & 0 & 0 \\
\hline & & $\begin{array}{l}\text { G. isingteena } \\
\text { (Nisegoishiutsubo) }\end{array}$ & 2 & 1150,1175 & 1 & 2 & 0 & 0 & 0 & 1 & 17 & 0 \\
\hline & Congridae & Congar cinereus (Kirianago) & 1 & 870 & 0 & 1 & 0 & 0 & 0 & 0 & 2 & 0 \\
\hline & Aulostomidae & $\begin{array}{l}\text { Aulostomus chinensis } \\
\text { (Herayagara) }\end{array}$ & 1 & 630 & 0 & 0 & 1 & 0 & 0 & 0 & 0 & 1 \\
\hline & Belonidae & $\begin{array}{l}\text { Tylosurus crocodilus crocodi- } \\
\text { lus (Okizayori) }\end{array}$ & 1 & 785 & 1 & 1 & 0 & 0 & 0 & 1 & 1 & 0 \\
\hline & Serranidae & $\begin{array}{l}\text { Plectropomus leopardus } \\
\text { (Sujiara) }\end{array}$ & 5 & $369 \pm 83$ & 0 & 1 & 1 & 0 & 0 & 0 & 1 & 1 \\
\hline & & P. laevis (Kokuhanara) & 1 & 363 & 1 & 0 & 0 & 0 & 0 & 2 & 0 & 0 \\
\hline & & $\begin{array}{l}\text { Cephalopholis urodeta } \\
\text { (Nijihata) }\end{array}$ & 6 & $174 \pm 13$ & 0 & 0 & 2 & 0 & 0 & 0 & 0 & 2 \\
\hline & & $\begin{array}{l}\text { Epinephelus ongus } \\
\text { (Namihata) }\end{array}$ & 2 & 193,255 & 0 & 0 & 1 & 2 & 0 & 0 & 0 & 1 \\
\hline & & $\begin{array}{l}\text { E. maculatus } \\
\text { (Shirobuchihata) }\end{array}$ & 3 & $334 \pm 5$ & 2 & 2 & 1 & 0 & 0 & 5 & 2 & 1 \\
\hline & Lutjanidae & $\begin{array}{l}\text { Lutjanus decussatus } \\
\text { (Amimefuedai) }\end{array}$ & 5 & $246 \pm 26$ & 1 & 0 & 2 & 4 & 0 & 2 & 0 & 3 \\
\hline & Lethrinidae & $\begin{array}{l}\text { Lethrinus atkinsoni } \\
\text { (Isofuefuki) }\end{array}$ & 12 & $262 \pm 28$ & 0 & 0 & 1 & 1 & 6 & 0 & 0 & 1 \\
\hline & & $\begin{array}{l}\text { Lethrinus olivaceus } \\
\text { (Kitsunefuefuki) }\end{array}$ & 1 & 332 & 0 & 0 & 1 & 0 & 0 & 0 & 0 & 1 \\
\hline & Sepiidae & $\begin{array}{l}\text { Sepia latimanus } \\
\text { (Kobushime) }\end{array}$ & 1 & 260 & 1 & 0 & 0 & 0 & 0 & 1 & 0 & 0 \\
\hline & Loliginidae & $\begin{array}{l}\text { Sepioteuthis lessoniana } \\
\text { (Aoriika) }\end{array}$ & 3 & $131 \pm 9$ & 0 & 0 & 2 & 0 & 0 & 0 & 0 & 2 \\
\hline & Octopodidae & Octopus cyanea (Wamondako) & 8 & $123 \pm 32$ & 0 & 1 & 1 & 1 & 1 & 0 & 1 & 1 \\
\hline & Ophichthidae & $\begin{array}{l}\text { Hydrophis sp. } \\
\text { (Umihebi-zoku) }\end{array}$ & 1 & 760 & 1 & 1 & 0 & 0 & 0 & 4 & 4 & 0 \\
\hline Total & & & 54 & & 9 & 9 & 13 & 8 & 7 & 17 & 28 & 14 \\
\hline \multirow[t]{14}{*}{2} & Muraenidae & G. melanospilos (Dokuutsubo) & 2 & 755,928 & 1 & 1 & 0 & 0 & 0 & 2 & 3 & 0 \\
\hline & & $\begin{array}{l}\text { G. isingteena } \\
\text { (Nisegoishiutsubo) }\end{array}$ & 1 & 1505 & 0 & 0 & 0 & 0 & 0 & 0 & 0 & 0 \\
\hline & Fistulariidae & $\begin{array}{l}\text { Fistularia commersonii } \\
\text { (Aoyagara) }\end{array}$ & 5 & $491 \pm 158$ & 1 & 0 & 3 & 0 & 0 & 1 & 0 & 3 \\
\hline & Serranidae & Variola louti (Barahata) & 2 & 355,409 & 0 & 0 & 2 & 0 & 0 & 0 & 0 & 2 \\
\hline & & $\begin{array}{l}\text { V. albimarginata } \\
\text { (Ojirobarahata) }\end{array}$ & 2 & 285,288 & 0 & 0 & 1 & 0 & 0 & 0 & 0 & 1 \\
\hline & & P. leopardus (Sujiara) & 1 & 352 & 1 & 1 & 0 & 0 & 0 & 2 & 4 & 0 \\
\hline & & C. urodeta (Nijihata) & 11 & $178 \pm 16$ & 1 & 1 & 1 & 1 & 0 & 1 & 1 & 0 \\
\hline & & E. ongus (Namihata) & 2 & 246,256 & 0 & 0 & 0 & 0 & 0 & 0 & 0 & 0 \\
\hline & & $\begin{array}{l}\text { E. polyphekadion } \\
\text { (Madarahata) }\end{array}$ & 1 & 243 & 0 & 0 & 0 & 0 & 0 & 0 & 0 & 0 \\
\hline & Lutjanidae & $\begin{array}{l}\text { Lutjanus kasmira } \\
\text { (Yosujifuedai) }\end{array}$ & 1 & 204 & 0 & 0 & 0 & 0 & 1 & 0 & 0 & 0 \\
\hline & & Lutjanus gibbus (Himefuedai) & 1 & 275 & 0 & 0 & 1 & 0 & 1 & 0 & 0 & 2 \\
\hline & Sepiidae & S. latimanus (Kobushime) & 1 & 196 & 0 & 0 & 0 & 1 & 0 & 0 & 0 & 0 \\
\hline & Octopodidae & O. cyanea (Wamondako) & 1 & 144 & 0 & 0 & 0 & 0 & 0 & 0 & 0 & 0 \\
\hline & Ophichthidae & $\begin{array}{l}\text { Hydrophis sp. } \\
\text { (Umihebi-zoku) }\end{array}$ & 1 & 759 & 0 & 0 & 1 & 0 & 0 & 0 & 0 & 2 \\
\hline Total & & & 32 & & 4 & 3 & 9 & 2 & 2 & 6 & 8 & 10 \\
\hline
\end{tabular}


Table 3 Incidence of predation on the released coral trout juveniles with time after release

\begin{tabular}{|c|c|c|c|c|c|c|}
\hline \multirow{2}{*}{$\begin{array}{l}\text { Release } \\
\text { trial no. }\end{array}$} & \multirow{2}{*}{$\begin{array}{l}\text { Days after } \\
\text { release }\end{array}$} & \multirow{2}{*}{$\begin{array}{c}\text { No. of } \\
\text { individuals } \\
\text { collected }^{* 1}\end{array}$} & \multirow{2}{*}{$\begin{array}{l}\text { Incidence of } \\
\text { predation }^{* 2}\end{array}$} & \multicolumn{3}{|c|}{ Mean no. of fishes in a stomach } \\
\hline & & & & Test group*3 & Control group*3 & Other fish \\
\hline \multirow{9}{*}{1} & 0 & 1 & 100 & 0 & 1.0 & 0 \\
\hline & 1 & 3 & 33.3 & 2.0 & 0 & 0 \\
\hline & 2 & 2 & 50.0 & 1.0 & 1.0 & 0 \\
\hline & 3 & 4 & 100 & 1.0 & 3.5 & 0 \\
\hline & 4 & 1 & 0 & 0 & 0 & 0 \\
\hline & 7 & 2 & 50.0 & 1.0 & 5.0 & 1.0 \\
\hline & 8 & 5 & 80.0 & 2.0 & 1.5 & 0.3 \\
\hline & 12 & 1 & 100 & 0 & 1.0 & 1.0 \\
\hline & 13 & 8 & 12.5 & 1.0 & 0 & 3.0 \\
\hline \multirow[t]{3}{*}{2} & 1 & 6 & 50.0 & 1.7 & 2.3 & 0.7 \\
\hline & 2 & 5 & 20.0 & 1.0 & 1.0 & 1.0 \\
\hline & 7 & 3 & 0 & 0 & 0 & 0 \\
\hline
\end{tabular}

*1 Species which preyed on the released coral trout juveniles during the sampling period.

*2 (No. of individuals which had preyed on the coral trout juveniles) /(no. of individuals collected) $\times 100$.

*3 See Table 1 for details of the test and control groups.

食量は絶食開始当初は低い值を示すが，飢餓状態の進行 にともない増加し, 肥満度 20 前後でピークを示すこと が報告されている。9) また, 絶食当初の低い捕食量は実 験時のハンドリングによる種苗のストレス状態に起因 し，飢餓の進行にともなう捕食量の増加は生理的摄餌要 求がストレスによる心理的不安を上回ることによるもの と考えられている。9) 今回の放流種苗の肥満度は馴致放 流群では放流 13 日後に, 直接放流群では 23 日後に 20 前後まで低下した（Fig. 4)。また，拤餌個体率は前者 では放流 13 日後, 後者では 23 日後に大きく増加して 打り（Table 1)，前述の飼育条件下の実験結果 ${ }^{9}$ に一致 した。

絶食下のスジアラ人工種苗の内臓重量指数は絶食当初 の減少率が大きく, その後も直線的に減少することが報 告されている。9) 第 1 回放流における馴致放流群の内臓 重量指数は放流 8 日後以降にほぼ安定した值を示した ことから（Fig. 4), 馴致放流群は摂䭒にともない飢餓 状態から回復しつつあるものと考えられる。

以上のように, 放流を起点に種苗の摄䬳と飢餓状態を 評価すると, 第 1 回放流では馴致放流群の方が直接放 流群より拱䬣個体率が速く増加し（Table 1), また飢餓 状態から回復しつつあると考えられることから（Fig. 4), 馴致放流群の方が環境への順応が速いものと判断 される。一方, 第 2 回放流では台風による環境攪乱に よって種苗を計画通りに再捕することができず，摂䬣に 及ぼす囲い網の効果を判断することはできなかった。

被食第 1 回放流では, 馴致放流群が 8 種 9 個体, 直接放流群が 7 種 9 個体の魚食性生物に捕食されてお り, 馴致放流群の被食頻度は直接放流群よりも低い傾向 を示した（Table 2)。馴致放流群では放流当初の見かけ
の滞留率が低い（Figs. 3，4）, すなわち囲い網による環 境馴致によってサンゴ等の間隙に隠れる能力が向上して いることが, 被食回避に有効に作用しているものと考え られる。人工種苗の被食回避に及ぼす放流場に設置した 囲い網による短期馴致効果は, ヒラメParalichthys olivaceus でも調査されて抢り，馴致期間が $0 \sim 7$ 日間の 範囲では収容期間が長いほど被食頻度が低くなる傾向が 示されている。16)

ヒラメの種苗放流では，陸上実験と実際の放流場にお ける調査結果に基づき, 飢餓が被食を加速するものと考 えられている。 ${ }^{17-20)}$ スジアラ人工種苗の飢餓と被食の関 係を調べた報告はないが，前述のように馴致放流群の方 が直接放流群より速く環境に順応し, 飢餓状態から回復 しつつあると考えられることから，囲い網による環境馴 致は飢餓による被食を回避する方向に作用するものと考 えられる。

一方, 第 2 回放流では, 4 種 4 個体の魚食性魚類が放 流種苗を捕食しており, 馴致放流群の被食頻度が若干低 い傾向を示したが，台風によって調査期間が短かったこ ともあり, 被食頻度の差は明確ではなかった。環境馴致 効果は飢餓状態が急速に進行する小型種苗でより有効と 考えられていることから, 9) 今回明確な結果が得られな かった小型の当歳種苗について, 再度調査を試みる必要 がある。

集中放流と被食 スジアラ放流種苗の被食尾数はその 他の魚類に比較して多く, 特に放流初期の被食尾数が多 かった（Table 3)。本邦に抢けるスジアラ天然魚の生息 密度に関する知見はないが, Light and Jones ${ }^{21)}$ はオー ストラリアのグレートバリアリーフで潜水観察を行い， 体長 $40 \sim 90 \mathrm{~mm}$ と $130 \sim 160 \mathrm{~mm}$ （全長と体長の回帰 
式15) から換算すると全長 $48 \sim 109 \mathrm{~mm}$ と $158 \sim 195$ $\mathrm{mm}$ ）のスジアラ天然魚の個体数を報告している。彼ら は 4 定点で調査を実施し, 各定点で 20 分間の潜水観察 を9 回繰り返した結果 (観察した総面積は約 $1500 \mathrm{~m}^{2}$ ), 20 分間に観察した平均個体数は最大 2 尾程度であった ことを示している (Light and Jones ${ }^{21)}$ の Fig. 2 からの 読反取り值)。この報告から $50 \mathrm{~m}$ 調査枠の面積（2500 $\left.\mathrm{m}^{2}\right)$ で観察が期待されるスジアラ個体数を計算すると 30 尾になり，この值と比較すると今回の放流尾数は 2 桁も多いことになる。このようなことから，放流初期に スジアラ種苗の被食尾数が多かったのは, $50 \times 50 \mathrm{~m}$ 程 度の狭い範囲で集中放流していることに起因する可能性 が考えられる。

今回のような放流手法を採用した場合，放流直後の種 苗の集中分布を防ぐことは困難であり，集中分布が被食 につながりやすいことになれば，放流手法自体を見直す 必要がある。このように, 放流初期の種苗の分布密度と 被食の関係は放流手法の選択に関わる重要な問題である ことから，その関係について捕食者の分布密度，捕食 量, 生活圈等を把握しながら詳細に検討する必要があ る。また, マダイ22)やヒラメ種苗23)では, 学習による 捕食者回避能力の強化によって被食頻度を低減できる可 能性が陸上実験で示されていることから，本種において も捕食者回避に打惊学習効果を研究する価值は高いも のと考えられる。

\section{謝辞}

本研究を進めるにあたり囲い網の設置と放流調査にご 協力いただいた日本栽培漁業協会八重山事業場の廣川 潤場長並びに職員各位に厚く抢礼申し上げる。また，放 流調査を補助いただいた当時の九州大学大学院修士課程 の岡本久美子氏に深謝する。論文の校閲を賜った日本栽 培漁業協会の古澤 徹常務, 廣瀬慶二参与並びに福永辰 廣部長に心より打礼申し上げる。

\section{文献}

1）片山正夫.スジアラ「日本産魚類大眓鑑」（益田 一，尼 岡邦夫，荒賀忠一，上野輝彌，吉野哲夫編）東海大学出 版会, 東京. $1984 ; 124$

2）海老沢明彦、スジアラの資源生態調査（水産生物生態調 査)。平成 8 年度沖縄県水産試験場事業報告書, 沖縄県 水産試験場, 那霸. 1998; 37-40.

3）海老沢明彦。スジアラの資源生態調査（水産生物生態調 查). 平成 9 年度沖縄県水産試験場事業報告書, 沖縄県 水産試験場, 那霸. 1999; 33-38.

4）浜崎活幸. 資源添加技術開発の概要，スジアラ。平成 11 年度日本栽培漁業協会事業年報, 日本栽培漁業協会, 東 京. 2002; 298-299.
5）手塚信弘. 資源添加技術開発の概要，スジアラ。平成 3 年度日本栽培漁業協会事業年報，日本栽培漁業協会，東 京. 1993; 313-314.

6）手塚信弘. 資源添加技術開発の概要，スジアラ. 平成 4 年度日本栽培漁業協会事業年報，日本栽培漁業協会，東 京. 1994; 269-270.

7）照屋和久, 浜崎活幸, 皆川 恵, 竹内宏行, 林原 毅, 佐野元彦，玉城泉也．石垣島浦底湾のサンゴ礁域に放流 したスジアラ人工種苗の滞留，摂飭打よび被食。水産増 殖 2003; 51: 151-156.

8）照屋和久. 資源添加技術開発の概要，スジアラ。平成 9 年度日本栽培漁業協会事業年報，日本栽培漁業協会，東 京. 1999; 307-310.

9）浜崎活幸，照屋和久，竹内宏行．スジアラ人工種苗の飢 餓耐性と絶食下の捕食量. 水産増殖 2003; 51: 65-71.

10）北田修一.「栽培漁業と統計モデル分析」共立出版，東京. 2001.

11) Umino $T$, Nakagawa $H$, Takaba M. Lipid accumulation and starvation tolerance in young red sea bream. Nippon Suisan Gakkaishi 1991; 75: 1897-1902.

12）宮木廉夫, 新山洋, 安元 進, 池田義弘, 多部田 修．トラフグ Takifugu rubripes 幼魚に打けるイラスト マ一蛍光標識の有効性について。長崎水試研報 1997 23: 27-29.

13) Zeller DC, Russ GR. Population estimates and size structure of Plectropomus leopardus (Pisces: Serranidae) in relation to no-fishing zones: mark-release-resighting and underwater visual census. Mar. Freshwater Res. 2000; 51: 221-228.

14) Tsukamoto K, Kuwada H, Hirokawa J, Oya M, Sekiya S, Fujimoto H, Imaizumi K. Size-dependent mortality of red sea bream, Pagrus major, juveniles released with fluorescence otolith-tags in News Bay, Japan. J. Fish Biol. 1989; 35: 59-69.

15）照屋和久，浜崎活幸，竹内宏行．スジアラ人工種苗の口 径と捕食したデバスズメダイの最大体サイズの関係．水 産増殖 2003; 51: 35-40.

16）古田晋平．放流技術と健苗性「放流魚の健苗性と育成技 術」(北島 力編) 恒星社厚生閣，東京. 1998; 94-101.

17）古田晋平，渡部俊明，山田英明，西田輝巳，富永貴幸. 鳥取県沿岸浅海域に放流したヒラメ人工種苗の分布，成 長および個体数変動. 日水誌 $1997 ; 63:$ 877-885.

18）古田晋平，渡部俊明，山田英明，富永貴幸。鳥取県沿岸 浅海域に放流したヒラメ人工種苗の摂䭒状態と䭒料条 件. 日水誌 $1997 ; 63: 886-891$.

19）古田晋平, 渡部俊明, 山田英明. 鳥取県沿岸浅海域に放 流したヒラメ人工種苗の被食. 日水誌 1998; 64: 1-7.

20）古田晋平. ヒラメ天然稚魚の拱食行動および被食に及ほ す飢餓の影響. 日水誌 1998; 64: 658-664.

21) Light PR, Jones GP. Habitat preference in newly settled coral trout (Plectropomus leopardus, Serranidae). Coral Reefs 1997; 16: 117-126.

22）藤川裕司, 佐々木 正. 人工種苗マダイの捕食者回避に 打ける学習効果. 水産増殖 2001; 49: 151-156.

23) Hossain MAR, Tanaka M, Masuda R. Predator-prey interaction between hatchery-reared Japanese flounder juveniles, Paralichthys olivaceus, and sandy shore crab, Matuta lunaris: daily rhythms, anti-predator conditioning and starvation. J. Exp. Mar. Biol. Ecol. 2002; 267: 1-14. 